石活技術協会誌 第 63 巻 第 5 号（平成10年 9 月）

JOURNAL OF THE JAPANESE ASSOCIATION FOR PETROLEUM TECHNOLOGY

VOL. 63, NO. 5 (Sept., 1998)

\begin{tabular}{ll}
\hline 資 & 料 \\
\hline
\end{tabular}

\title{
石油公屉石油開発技術センターの掘削
}

\author{
関連研究プロジェクトについて* \\ 畠山孝**米澤 哲夫・鈴木 孔 孔**
}

(Received June 12, 1998; accepted July 13, 1998)

\section{Recent drilling project in Technology Research Center of Japan National Oil Corporation}

Takashi Hatakeyama, Tetsuo Yonezawa and Akira Suzuki

\begin{abstract}
Drilling Technology in the oil industry is the technology required to drill wells for exploration and production of oil and gas resources. JNOC-TRC's Drilling and Completion Lab. is engaged in research and development ( $R \& D$ ) with three main goals:drilling cost reduction, drilling in challenging frontiers and environmental safety in drilling. This $\mathrm{R} \& \mathrm{D}$ effort also covers the well completion technology needed to produce oil and gas from the wells drilled. R \& D has been carried out to date under the three pillars of basic research, large-scale research and specific (applied) research. Recent trends in R \& D including horizontal well technology, slim-hole drilling technology and methane hydrate technology will be introduced here.
\end{abstract}

Key words : horizontal well, slim-hole, methane hydrate

\section{.1.はじめに}

石油公団石油開発技術センターは，昭和 47 年 7 月に 「石油及び可然性天然ガス資源開発審議会」の答申に基 づき，当時の外国石油開発会社と我が国の石油開発会社 との間の技術的な格差を早急に解消するために，石油開

* 平成 10 年 6 月 2 日, 平成 10 年度石油技術協会春季講演会作 井部門シンポジゥム「近年の掘削技術の動向之将来への展 望」で講演 This paper was presented at the 1998 JAPT Drilling Technology Symposium entitled "The latest drilling technology and the future prospect" held in Sapporo, Hokkaido, Japan, June 2, 1998.

**石油公団石油開発技術センター掘削技術研究空（現在，帝 国石油(体) Drilling and Completion Laboratory, Technology Research Center, Japan National Oil Corporation, presemtly Teikoku Oil Co., Ltd.

***石油公団石油開発技術センター掘削技術研究室 Drilling and Completion Laboratory, Technology Research Center, Japan National Oil Corporation.

Copyright (C) 1998, JAPT
発関連技術の開発・導入 ・向上, 石油開発関連企業への 技術サービス，石油開発技術者の養成などを集中的，総 合的に行うことを目的に設立された。

その後, 昭和60年の「石油開発技術研究推進委員会」 の答申に沿って，我が国の石油開発技術水準の一層の向 上を目指して，昭和63年には石油開発技術センターの新 施設を現在の干葉県千葉市に建設し，さらに平成 4 年に は, 研究開発成果の実証試験任老行5目的で, 新憈県 柏崎市にテストフィールドを完成するなど，研究開発業 務の充実を図ってきた。

さらに平成 7 年度には, 石油開発業界, 関連業界, 大 学, 国立研究機関の学識経験者を委員とする「石油・天 然ガス開発技術委員会」を新たに設置して，石油探鎕開 発技術の総合的かつ中長期的な施策; 今後の石油開発技 術センターの研究開発業務の進め方; 研究評価管理なら びに研究成果の活用および技術サポート業務などの強化 策について検討してきた。

その結果, 平成 8 年度から石油開発技術センターでは 
表 1 石油開発技術センターの沿革

\begin{tabular}{|c|c|}
\hline 昭和 47 年 7 月 & $\begin{array}{l}\text { 石油開発公団の付置機関として第21森ビルを仮事務可として発足 } \\
\text { 「石油及び可燃性天然ガス資源開発蕃議会」の答申 }\end{array}$ \\
\hline 12月 & 地質探鉱研究室，開発技術研究室，油層研究室および業務課設置 \\
\hline 昭和 53 年 12 月 & 開発技術研究室の室内実験部門を石油資源開発㑣技研に設置 \\
\hline 昭和 55 年 3 月 & 富国生命ビルに移転 \\
\hline 昭和60年 & 「石油開発技術研究推進委員会」の答申 \\
\hline 昭和61年 7 月 & 開発技術研究室の一部を水道橋の日本生命ビルに移転 \\
\hline 10 月 & 石油公団技術研究所 (仮称) 用地を取得。（千葉市浜田 1-2-2) \\
\hline 昭和61年11月 & 石油開発技術センターの新研究施設竣工 \\
\hline 平成元年 5 月 & 海外技術者研修事業開始 \\
\hline 平成 4 年 8 月 & 柏崎テストフィールド峻工 \\
\hline 平成 7年 7 月 & 「石油・天然ガス開発技術委員会」の答申 \\
\hline 平成 8 年 5 月 & 採油增進研究窒と油層研究室を，油層研究公に合併 \\
\hline & 開発技術研究室を掘削技術研究室上生産技術研究室に分離 \\
\hline & $\begin{array}{l}\text { 研究評価管理システム,「操業ニーズ支援調查事業」, } \\
\text { 「官学交流調查事業」,「フェローシップ事業」。 }\end{array}$ \\
\hline
\end{tabular}

従来の業務に加えて, 新たに研究評価管理システムムの導 入; 操業支援型研究開発の拡充を目指した「操業ニーズ 支援調查事業」の害施; 大学研究者との交流を通じて将 来の石油開発技術に応用可能な先端的ないし基礎的な シーズの調査を行う「官学交流調査事業」; 産油国との 人的友好, 協力関係を強化するための「フェローシップ 事業」などを開始した。

また，時代のニーズにあった研究開発を実施すべく， 研究室の再編成として平成 8 年 5 月に, 採油増進研究室 と油層研究室を合併して油層研究室に, 開発技術研究室 を掘削技術研究室と生産技術研究室に分離した（表 1 )。

\section{2. プロジェクトの概要}

石油開発産業における「掘削技術」とは, 石油・ガス 資源を探鉱・生産するために不可欠な坑井を掘削する技 術を指すが，掘削技術研究室では，掘削した坑井から石 油・ガスを生産するための仕上げ技術までを含めて, 「コストの削減」「「ロンティアへの挑戦」扔よび「環 境への順応」の3つの棵題を念頭に研究開発に取り組ん でいる。研究テーマについては, 経常研究, 大型研究,

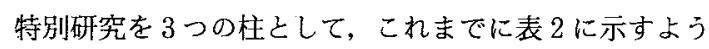
な研究開発を実施している。「経常」は, 各研究室独自 の基礎的な研究, 「大型」は先端的かつ広範囲に応用が 期待できる研究，「特別」は石油会社の要望に基づき緊 急度が高く，操業支援的な研究を目的としたものであ る。今回はこの中から, 特に近年の掘削技術の動向とし て注目されている「水平坑井開発技術」,「スリムホール 掘削技術」抢よび「メタンハイドレート開発技術」につ
いて紹介する。

\section{1 水平坑井開発技術}

水平坑井は，垂直坑井に比べて，坑井産油能力が大き く, 可採埋蔵量の増加および開発投資額の低減をもたら す。当該研究の目的は，掘削技術分野にお打る先進技術 を開発し，水平坑井適用技術の向上を図ることである。 技術テーマとして, 地表から掘進方向（方位・傾斜）の 制御が可能な坑底・地上機器開発を中心とした「リモー トコントロールダイナミックオリエンテーションシステ $\Delta(\mathrm{RCDOS})$, 適正な仕上げ計画立案のためのガイド ライン作成を日的とした「仕上げ技術」, 国内石油開発 会社の操業支援を目的とした「マルチラテラル坑井の仕 上げ技術」などの研究開発を実施している。このうち 「仕上げ技術」については，坑井クリーンアップ作業, アンダーバランス掘削技術招よび大偏距掘削技術につい てマニュアル化し, 技術普及に努めた。また, 地層検層 技術では，LWD (logging while drilling) 用センサー としてのパルス中性子センサーの開発を実施している。

\subsubsection{RCDOS (リモートコントロールダイナミック オリエンテーションシステム) の研究開発}

(1) 目 的

水平坑井掘削技術における坑跡制御技術を確立するた めに, 地表から信号を送り, ビットの曲げ角度, ビット フェース抢よび方位角を自由に变え，坑跡を制御するシ ステムを開発することによって, 上り正確な坑井の方 位・傾斜制御を可能にするとともに，掘削効率を改善 し, 開発コストの減少を図る。

(2) 概 要 
表 2 石油公団の掘削関連プロジェクトの主な研究テーマ（期間）

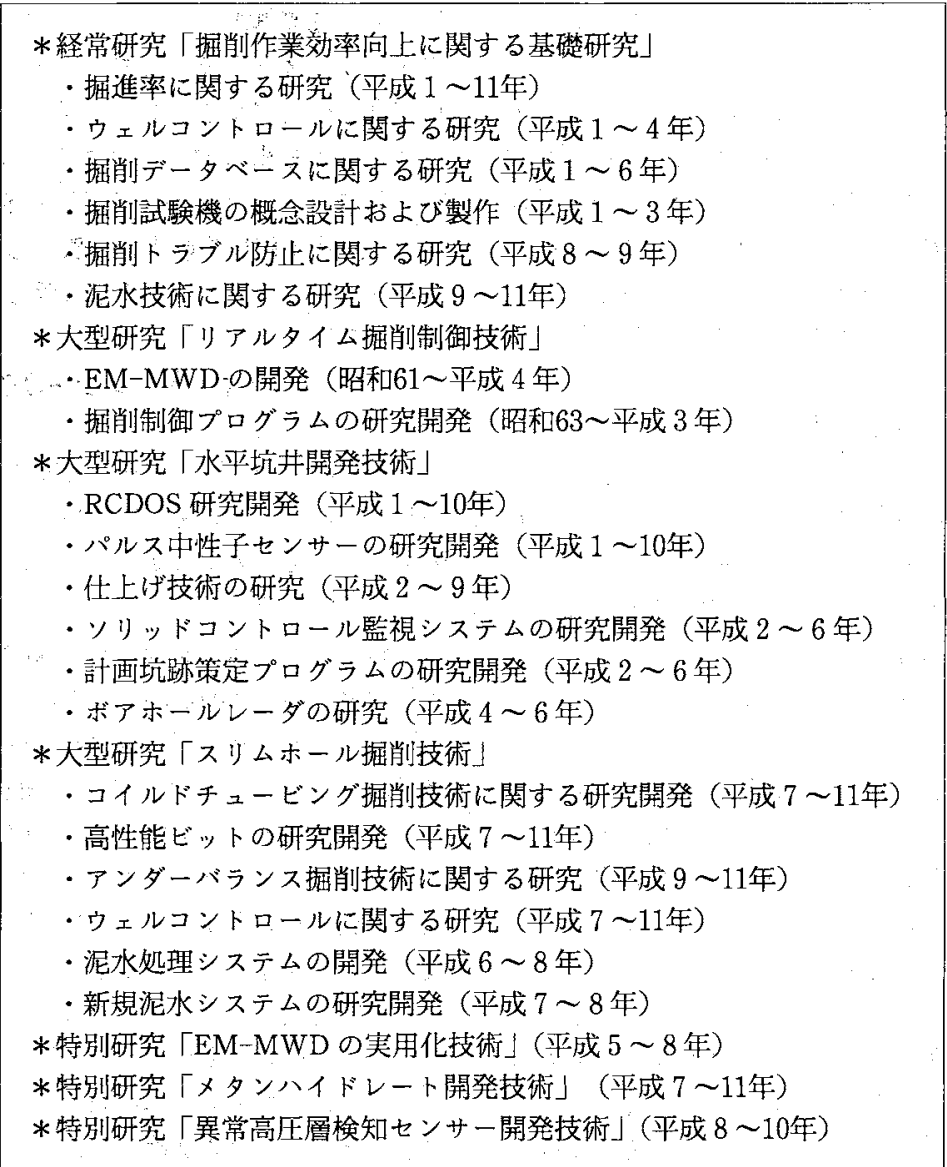

平成元年度より,リモートコントロールで制御する傾 斜コントロール坑底機器 RCDOS の研究開発を実施し ている。これまでに，12-1/4”坑用プロトタイプおよび 8-1/2”坑用プロトタイプを製作し， $12-1 / 4^{\prime \prime}$ 坑用プロト タイプは，柏崎テストフィールド実験井の掘削試験によ り，地表坑底間の双方向通信，增角性能などの確認を 行った。さらに，水平坑井の坑井軌跡制御技術を完成さ せるためには，モー夕を使ったスライディング掘削によ る方位傾斜制御に加えて，ロータリーモードにおいて同 様の制御を可能とするロータリースティーラブルシステ 厶が必要であり，現在開発中である。平成 9 年度から は, SPERRY-SUN 社と共同開発契約を締結し, 同社 と石油公団がプロジェクトチームを結成して新たな休制 下で，平成10年度内に RCDOS プロトタイプ商用機の 完成を目標とした研究開発を進めている。

\subsection{2 マルチラテラル坑井の仕上げ技術開発}

(1) 目的

中東の巨大油田の上部油層を対象に; 各デテラル坑に
必要に心じてアクセス可能なマルチラテラル井への仕上 げ技術の研究開発を行う。マルチラテラル井の坑跡と仕 上げ技術の最適化スタディを, 地質, 油層, 掘削・任上 げ各部門の担当者が互いに協力して行い，対象油層の生 産能力の增加, 回収率の向上, 水つき問題の軽減, 長期 にわたる油層管理を可能とする方策を現地へ提供する。 現地への有益な技術移転を行う上で，対象油層の二ー ズ，環境などを分析すると同時に，他の油層・油田への 将来的な適用も考慮に入れ，本研究を推進する。

(2) 概 要

ジャパン石油開発條と石油公団石油開発技術センター は，中東現地への操業支援の一環として，「マルチラテ ラル坑井最適化による上部油層挙動の改善」を実施して いる。当該油田に和ける水平坑井の㗇削は平成元年より 開始され，現在までマルチラテラル坑井を主体に約70坑 の水平坑井が掘削されている。現地では, 水平玾井掘削 技術の急激な進歩と幾多の知識・経験の蓄積により, 掘 削上の問題点のほとんどが解決されており，近年の技術 
的関心は, マルチラテラル坑に対し, 選択的な坑井刺 激, 油層モニタリングを可能とする仕上げ技術の導入と その最適化任移行しつつある。特に, 当該油田のように 海上プラットホームのスロット数が限られている状況下 では, 既存井からのマルチラテラル坑の掘削が不可避で あり，それに即した仕上げ技術の適用が今後の重要課題 となる。既存井から掘削されたマルチラテラル坑井の仕 上げ技術に関しては，世界的にすいまだ発展途上にあ り，掘削技術に即した仕上げ方法および仕上げ機器に係 る研究開発が求められている。

\subsection{3 仕上げ技術の研究開発}

(1) 目 的

水平坑井の仕上げ計画立案において，水平玾井の要素 技術や作業実施手䐓に対する知見を踏まえ, 油層特性, 目的に即した仕上げ方法および技術を選定するための最 適手法を確立すべく，包括的なガイドブックとして「水 平玾井什上げデザインガイド」を作成する。

(2) 概 要

水平坑井仕上げ技術に関して，国際共同研究への参加 やセミナーの開催などを通じ, 仕上げ要素技術の現状お よび各技術の作業実施手順に重点を置いて最新事例調査 研究を実施した。その結果, 水平坑井を検討する際, 油 層特性ほかに関する事前検討が不十分なために, 生産目 標を達成することができない坑井が少なからず見られ， 水平坑井の仕上げ計画立案において，水平坑井の要素技 術や作業実施手順に対する知見を踏まえたうえで，油層 特性之目的に応じた仕上げ万法を選定することが重要な 技術課題であると認識された。そこでこれら課題に対し 調查，検討を実施し，油層特性，目的に即した仕上げ方 法および技術を選定するための最適手法の確立を目的と した包括的なガイドブックである「水平坑井仕上げデザ インガイド」を作成することにした。このため過去の調 查, 検討結果を踏まえて, 特に注目されてきた仕上げ技 術分野であるマルチラテラルおよびマルチブランチ技術 ならびに油層障害削減について調查し，仕上げ方法およ び技術を選定するための最適手法の検討を哚めた。その 内容を「水平坑井仕上げデザインガイド」の一部のデザ インガイドとして，マルチラテラルとマルチブランチ技 術（デザインガイドVOL. 2) および油層障害削減（デ ザインガイドVOL. 3）として補足した。

また「水平坑井什上げデザインガイド」の検証を目的 として，アラビア石油蛜力フジ油田と合同石油開発㑣)の エルブンドク油田に扔ける最適仕上システムのケースス タディを実施した。

さらに公表文献や訪問調查等による事例調查を行い, 掘削, 仕上げ計画最適化の検討を深め,「水平坑井仕上
げデザインガイド」の一貫として坑井クリーンアップ作 業における新規技術（デザインガイドVOL. 4)，アン ダーバランス掘削技術（デザインガイドVOL. 5)，大偏 距掘削技術（デザインガイドVOL. 6)，坑井刺激作業に おける新規技術（デザインガイドVOL. 7）および坑井 穿孔作業（デザインガイドVOL. 8）として補足した。 また，最新事例情報収集の一環として欧米の石油会社の 最新の実フィールドデータを入手し，その評価や分析に 役立てている。

\subsection{4 パルス中性子センサーの研究開発}

(1) 目 的

パルス中性子検層を将来の LWD の重要な検層種目之 判断し, LWD 用に適した小型のパルス中性子発生器の 開発とこれを使用する検層システムの開発を行う。

\section{(2) 概 要}

検層システムは, 検層機能の開発として孔隙率評価, 水飽和率評価, 油層識別, 岩相識別の 4 種類の検層機能 を目標に，モデリングに関する基礎研究，プロトタイプ 機設計，拈よびワイヤーライン検層機とのコンビネー ションで測定を行うプロトタイプ機を製作し，実証試験 を実施した。ワイヤーラインベース・プロトタイプ機の 実証試験の結果を受けて，LWD型のプロトタイプ機の 設計および製作を行うとともに，キャラクタリゼーショ ン作業を実施している。パルス中性子発生器の開発とし ては，小型化改良設計を行って試作するとともに，試作 したパルス中性子発生器に対し, LWD 用パルス中性子 発生器としての性能試験を行い, 性能を確認した。

\section{2 スリムホール掘削技術}

近年，世界的に掘削コストの大幅な削隇を目指したス リムホール掘削技術が大きな注目を集めている。当該研 究の目的は，スリムホール掘削技術の確立を図るべく， ビット，ドリルストリング、コイルドチュービング, ウェルコントロール，掘削流体システムほかの各要素技 術に関して研究開発を実施すること，ならびにスリム ホール掘削システムとして，特にコスト効果执よび応用 範囲の広さなどの観点から, 最もポテンシャルの高いコ イルドチュービング掘削 (CTD) に着目して, 要素技術 の研究開発加ら得られた成果を活用することにより総合 システムとして確立し，国内石油開発会社に技術普及を 図ることである。

\section{2 .1 高性能ビットの研究開発}

(1) 目 的

高性能スリムホールビットの開発には，硬質岩殸削に おけるトリコンビットおよび PDC (polycrystalline diamond compact) ビットの高寿命化が課題である。こ れらの課題を克服するために，日本が保有する高度なダ 
イヤモンド焼結技術および CVD (chemical vapor deposit）ダイヤモンド技術を活用し，「PDCビット用高強 度ダイヤモンド焼結体枋よび同ロウ付け技術の開発」な らびに「トリコンビット用CVD ダィヤモンドコーティ ングベアリングの開発」について研究開発を実施する。

(2) 概 要

ダイヤモンド焼結技術は，超高圧・高温環境下でダィ ヤモンド粉末朽よび結合材（金属または非金属触媒）か ら, 超高圧・高温容器を使用して高強度のダイヤモンド を生成する技術である。また CVD は，さまざまな形状 に膜状のダイヤモンドを成長させることが可能な応用範 囲の広い気相ダイヤモンド合成技術であり, 熱フィラメ ントを使用してコーティングを行う。

PDC ビット用高強度ダイヤモンド燒結体の開発では, ダイヤモンド焼結体が有する耐熱性，耐衝撃性および圧 縮強度の 3 つの特性值について, フィージビリティス夕 ディの開発目標を定めた。これら目標値を達成するため に, ダイヤモンド粒子を結合する材料に着目し, 炭酸、 グネシゥム類および希土類燐酸塩類などの非金属触媒を 選択した。この結果, 耐熱性 : $1,200^{\circ} \mathrm{C}$, 而衝撃性を示 す指標として破壊勒性值：11１2（現状 PDC の約 2 倍） および圧縮強度：1,300 kgf $/ \mathrm{mm}^{2}$ (現状： $400 \mathrm{kgf} / \mathrm{mm}^{2}$ ) という優れた值が得られた。またこの結果を得て, HYCALOG 社との共同研究として高性能 PDC ビット を開発することになり，同社により同焼結体を評価した ところ, 他社 PDC の100倍以上の耐摩耗性を示した。 なお今後の大きな課題は, PDC とビットボディとのロ ウ付け強度である。

トリコンビット用 CVD ダイヤモンドコーティングベ アリングの開発では, 基礎研究目標を, ベアリングに適 用するために最も重要である耐摩耗特性について, 泥水 中で従来焼き入机鋼の10倍としたが，CVD ダイヤモン ドの耐摩耗特性を測定したところ, 目標值を大幅に上回 る約 500 倍の対摩耗性が得られた。実際のベアリング材 料にコーティングを施した耐摩耗試験では，はく離を伴 わずに300時間以上の長寿命を得ることができた。また 実際のビットベアリングを想定したブッシング類の円筒 形状内面执上び平面状のスラストワッシャーへの均一な コーティングが可能であることを確認した。現在,ビッ トベアリングを試作し，耐久試験を実施している。

\section{2 .2 ドリルストリングに関する研究開発}

(1) 目 的

小径ドリルストリングを使用しなければならないスリ ムホール掘削では，ストリングの強度が従来よりあ小さ いことから，ドリルストリングは厳しい環境下におかれ ることとなる。これらに起因するトラブルを回避するた
めに，掘削計画立案時にドリルストリングの応力解析お よび機械的強度特性の把握を行い,ドリルストリングに 発生するトルク，ドラグおよび，座屈現象などをシミュ レートし，ホールクリーニングなどを考慮した上で，こ れら応力を軽減できる最適な坑跡および最適なドリルス トリングを選択するプログラムを開発する。

(2) 概 要

最適な坑跡は安全な掘削が可能で，コストが最小とな る坑跡であるが，そのためにはトルクドラッグや坑跡長 が小さくなるような坑跡を求め, シミュレーションによ りその坑跡およびドリルストリングの妥当性を確認する 必要がある。そのため本プログラムは，坑跡設計とドリ ルストリング設計の 2 つの計算機能を有する。坑跡設計 では, トルク，フックロードあるいは坑跡長などを最小 にする坑跡を，さまざまな制約を満たしながら，最適化 計算に有効な非線形計画法を利用して求めることができ る。また，本プログラムでは複数の坑跡デー夕を三次元 画面に表示することができ，他坑跡との干涉の計算機能 が加えられている。ドリルストリング設計では，ユー ザーが入力したドリルストリングがさまざまな条件を満 足するかどうかをシミュレーションによって確認する。 座屈については, 基礎的な理論式（オイラーの座屈式） を改良して新しい座屈式を導き，ストリングを分割した 各セグメントに対してこれらの式を適用してドリルス トリング全体の座屈挙動を追跡できるようにした。

\subsection{3 高性能コイルドチュービングの研究開発}

\section{(1) 目 的}

近年のコイルドチュービング掘削が適用される石油ガ ス井の深井戸化に対応するため，高強度でありしかる繰 り返し使用に耐えうる高寿命コイルドチュービングを開 発する。

\section{(2) 概 要}

既存のコイルドチュービングは，帯板をロールで成形 し誘導加熱により溶接して製造する電縫溶接鋼管 (ERW) が用いられているが，厚肉・高強度 $\mathrm{ERW}$ 鋼管 を製造することは必ずしも容易でない。一方，中実ビ レットを穿孔し圧延によって製造する継目無銅管は，石 油ガス井開発の分野において強度や信頼性が要求される 用途に対して幅広く使われて扔り，厚肉・高強度化に対 応しやすい特長を持っている。ただし，既存の継目無鑐 管は，出荷される製品長さが十数 $\mathrm{m}$ と短いため, 3,000 〜4,000 $\mathrm{m}$ に及ぶコイルドチュービングとするために は，周溶接によって繰返し接合する必要があり，高強 度・高疲労寿命・高能率な周溶接法が必須である。各種 溶接法を調查し，板状試験片を用いた溶接継手性能の簡 易試験を実施した結果，従来溶接法では GTAW（gas 
tungsten arc welding) の疲労寿命特性が優れていた。 一方, ADB (amorphous diffusion bonding) で接合し た武験片は絽返し曲げ疲労寿命が高く，安定した溶接性 能が得られるなどの特長を持つことから，ADBを用い た高性能コイルドチュービング開発のできる可能性が高 いと判断し，ADBを高性能コイルドチュービングの製 造に応用することにした。当該研究開発考国際共同研究 DEA107 Project として, AGIP, AMOCO, BP, Scottish Enterprise の参加により実施している。本プロジェク トにおいて, ADB と従来溶接法である GTAW の比較 試験を実施した結果, ADB が GTAW に比べ 2 倍以上 の疲労寿命を有することを見いだした。本プロジェクト の成果として, 最適材質拉よび最適接合条件を明ら加に し、リールに巻き取った高性能コイルドチュービングを 試作する。

\subsection{4 ウェルコントロールに関する研究}

(1) 目 的

ハイドロリクス, ウェルコントロール手法, キック検 知技術について, 各要素技術を組み合わせ, スリムホー ルを安全に掘削するためのウェルコントロール手法の確 立を目指す。

(2) 概 要

コンベンショナルホールと比ベ，スリムホールはドリ ルパイプと坑壁のクリアランスが小さいししたがってパ イプの回転と坑内におけるパイプの偏心（エキセントリ シティ）に伴うアニュラス压力損失およびパイプ揚降管 中に起こるサージ压，スワブ压などのハイドロリクスの モデル化，精度よいキック検知技術の確立，ガスマイグ レーションスピードの把握等が重要であり,これらを考 慮したスりムホール独自のウェルコントロール技術の開 発が望まれている。ハイドロリクス，キック検知システ ム, ウェルコントロール手法の現状技術動向を調查した 結果, 既存モデルの活用を含め, スリムホールウェルコ ンドロールマニュアルの作成, ならびにスリムホール ウエンコントロール教育システムの構築などが重要々判 断した。マニュアルの作成では, キックの早期検知用機 器を考虑し，既存のキックシミュレーターを活用しなが ら，特定のスリムホール掘削におけるキックの防止方 法, キックの早期検知方法, キック発生時のコントロー ル方法などを網羅したスリムホールウェルコントロール マニュアルを作成した。また教育システムの構築では, スリムホールにおけるキックコントロールの問題点・重 要性，その具体的コントロール方法などを網羅し，掘削 クルーなどにすより理解しやすい教育システムを製作し た。今後, スリムホールに扔けるキックコントロール手 法やキック検知方法を検証するため，実験内容，“方法，
実験設備, 人員計画, デー夕解析方法などを中心に柏崎 テストフィールドの既存井を利用した実証実験を実施す る予定である。

\subsection{5 環境融和型泥水システムの開発}

(1) 目 的

泥水コスト削減のために, 1 坑井の掘削作業におい て, 1 種類の泥水システムで掘削が可能でかつ各種添加 剤類は有害物を含まない環境融和型泥水システムを開発 する。

\section{(2) 概 要}

泥水コントロールにおいて, 高温・高比重になった場 合には，泥水流動性のコントロールのため必然的に分散 剂が使用されるが，最も代表的に使用されるのが重金属 を一部含む分散㓮である。しかしながら世界的に環境保 護規制が強化されつつある状況で，これと同等機能を有 する代替品を開発することが必要である。また 1 坑井の 㻕削においては坑井条件が種々変化するため, 1 種類の 泥水システムで掘削されることはまれで, 通常 $2 \sim 3$ 種 類の泥水システムが組み合わされて使用されており，泥 水コストを增加させる要因となっている。このため現 在, 一般的に使用されているクロムリグノスルフォネー 卜泥水中のクロム含有添加剤 (分散剂) に替水る新規お よび既存分散剤の評価試験を実施し，有効性の高い分散 版の選択を実施し，清水および塩水べース（KCl を含 む）で， $175^{\circ} \mathrm{C} て ゙$ 定な泥水システムを構築した。また 泥水添加剤の変更のみで泥水システムを変換する技術を 確立した。

\section{2 .6 泥水処理技術の開発}

(1) 目 的

経济的かつ効率的な泥水の処理技術の確立はるとよ り, 産業廃裹物処分場の確保難を考慮し, 処理物の減容 化ならびに再資源化をす可能とする処理技術を開発す る。

(2) 概 要

現在, 国内で一般的に実施されている廃泥水の压入処 理については，その安全性について是非が問われてお り, 将来的に廃止される可能性が高く, 安価でかつ効率 的な処理技術の確立が望まれている。また国内では蒸発 濃縮式による廃泥水処理技術が開発されたが, 本装置で は固形分30\%程度までの濃縮が限界であり，濃縮物につ いては固化処理されて産業廃童物処分場へ搬入し処分さ れている。しかし近年, 産業廃㲤物処分場を確保するこ とが困難になりつつあり，搬入する廃棄物の受け入れ単 価や運搬費の高騰を考えた場合, 廃棄物の減容化が求め られているところである。さらに蒸発濃縮装置の 1 日当 たりの処理能力は $72 \mathrm{k} l$ が最大であるため。これを超え 
る分については压入処理との併用を行っているのが現状 である。したがって蒸発濃縮式による廃泥水処理の実用 化には難題が課せられている。このような背景から，国 内の污泥処理会社および処理装置の製造・販売会社を調 查し，高压ポンプを使用した脱水処理装置，および污泥 改質固化処理装置が泥水処理システムとして有望である と判断した。ラボテストによって高圧脱水処理装置に関 しては，処理量，ランニングコストとも満足できる結果 が得られたが，ろ水の品質などの課題があり，フィール ドテストによってコストを含む総合評価を行う必要があ る。污泥改質固化処理装置に関しては，処理量は現状以 上のむのが得られ，かつ再資源化に最も近い処理方法で あるが, ランニングコストが従来の約2倍となった。こ れは坑井内における処理コストはほぼ同様であるが, 坑 井敷地外に搬出するための運搬費が約 2 倍になるためで ある。いずれの装置も処理面での効率は確認できたが, まだ経済的な課題があり, 今後,フィールドテストを通 じて実用化の検討を実施する予定である。

\subsection{7 コイルドチュービング (CT) 掘削技術の研究}

(1) 目的

コスト効果および沉用性において，今後の掘削作業に 有效利用が期待される CT 掘削技術について, 本邦石油 開発会社などに技術普及を図る。

\section{(2) 概 要}

高性能 CT の研究開発， CT 坑底機器および CT 掘削 リグの調査，CT掘削マニュアルの作成，ならびにアン ダーバランス掘削技術の研究開発を行い，これらの成果 を活用し，総合システムとして確立すべく研究開発を実 施している。上述した高性能 CT の研究開発のほかに, CT 坑底機器に関しては, 国際共同研究としての PROJECT HELIXにおいて，ダウンホールモータ，MWD (measurement while drilling)などの概念設計を実施 した。またアンダーバランス掘削技術の研究開発では, ベネズエラ国 INTEVEP との共同研究として，ホール クリーニング扔よびハイドロリックコントロールを目的 とした多相流体挙動シミュレータの開発を実施してい る。

CT 掘削は現段階では，ある限られた適用に扔いて非 常に有效な手段となっている。当初はコンベンショナル リグの欠点を補う目的によるものが多かったが, 今日で は単一システムとしてあ経済性および技術的信頼性が向 上しつつある。一方，アンダーバランス掘削を経済的に 総合評価することは非常に難しいが，CT がアンダーバ ランス掘削を行うための最す優れたッールであることは 確かである。今後もCT 掘削の技術発展㧍よび適用数増 加が予測され、コンベンショナル掘削にはない利点を
持っていることから，その動向について継続的に着目し ていくことが重要である。

\section{3 メタンハイドレート開発技術（掘削技術関連）}

近年, 非在来型のエネルギー資源として世界的にも脚 光を浴びているメタンハイドレートは，我が国でもその 存在が知られており，未来のエネルギ一源として注目さ れている。この開発技術を確立することを目的として, 掘削技術研究室だけでなく TRC 全体の研究テーマとし て取り組えでいる。掘削技術分野では，坑内温度・圧力 シミュレーション技術拉よびキックコントロール技術に ついて研究を実施するとともに，セメンチング扔よび ケーシングデザインに関する調查, 泥水システム, 泥水 冷却装置抢よびコアサンプラーの開発を実施している。

\subsection{1 坑内温度・圧カシミュレーション技術の研究}

(1) 目 的

メタンハイドレート層掘削を含む大水深掘削の状況を 正確に模擬し，泥水物性值の温度依存性やライザ一。 チョークラインの伝熱現象ほかを正確に表現して坑内温 度・圧力の計算ができるコンピュータシミュレーション プログラムを開発する。

(2) 概 要

メタン八イドレートの分解・生成は, 主に圧力のみを 考慮すればよい通常のガス層と異なり，圧力のみならず 温度にも大きく依存する。したがって，メ多ンハィド レート層の掘削・仕上げ作業を計画する際は，その作業 ごとに, 玾井内の圧力と温度の両方を正確に知り, メ夕 ンハイドレートの原位置での状態を推測して，作業を安 全に進められるかどうかの判断をする必要がある。坑内 温度・圧力シミュレーションプログラムを製作し，計算 部とグラフィカルユーザーインターフェイス (GUI) 部 とを結合した 1 つのシステムとして構築するとど屯に， 基礎試錐「南海トラフ」の予想掘削データセットを作 成・入力し，その機能を检証しながらシステム調整を実 施している。

\section{3 .2 キックコントロール技術の研究}

(1) 目 的

大水深掘削に対応したメタンハイドレート層掘削作業 に必要不可欠なキックコントロールシミュレーションプ ログラムを開発する。

(2) 概 要

メタンハイドレート層掘削におけるキックコントロー ルは，分解・生成という物性上の特徴を持つメタンハ1 ドレート自身についての考慮が必要なことはもちろんの こと，その賦存環境である大水深海域での掘削について の考慮（長大なチョークラインによる摩擦損失の増大， 地層破壊圧の低下，低温環境など) む必要になるという 
特殊性を持つ。したがって，ハイドレート層掘削を安全 に遂行するには，これらの特殊性を考慮したキックコン トロール方法をシミュレーションで検討し, 安全で確実 なキックコントロール手法をあらかじめ確立しておく必 要がある。キックコントロールシミュレーションプログ ラムを製作し, 計算部とグラフィカルユーザーインター フェイス（GUI）部とを結合した 1 つのシステムとして 完成し，この中で温度データをリンクする圧力・温度イ ンターフェイスモジュールを組み込んだ。さらにシミュ レーション実験データを入力し, 実験結果を検証しなが らシステム調整を実施している。

\subsection{3 セメンチング技術の調查}

(1) 目的

メタンハイドレート坑井のセメンチングに求められる 要件之技術を, セメント硬化熱, 断熱性, 低温強度発 現，大水深対応，アニュラーガスフロー防止などの観点 から検討し，海上基礎試錐の坑井条件に最適と考えられ るセメンチングシステムを確立する。

(2) 概 要

メタンハイドレート玾井のセメンチングには，一般的 な油・ガス井の場合に必要とされる要件に加えて，坑井 からの熱伝導によるメタンハイドレートの分解を最小に する断熱性, 大水深の海底付近の低温環境での良好な流 動特性や物理的性状, 大水深の浅層部における強度の弱 い地層を破壊しない低比重性ほかの要件を満たすセメン チングシステムが要求される。永久凍土地域や大水深海 域などでのセメンチングの実績と技術の現状について調 查し, 永久凍土あるいは大水深自体に特有の問題の克服 を意図するスラリ以外は，通常の油・ガス井と同様なセ メントや添加剂が使われていることを確認した。これら の調查検討に基づき，日本近海のメタン八イドレート坑 井のセメンチングは, 業界ですでに実用化されている技 術を適用するのが妥当であろうと判断した。

\subsection{4 ケーシングデザイン技術の調查}

(1) 目的

メタンハイドレートが分解・生成した場合に坑井内の ケーシングが受ける影響を検討し，メタンハイドレート 坑井に適用すべきケーシング設計方法を確立する。

(2) 概 要

メタンハイドレートが分解・生成した場合に, 坑井内 に設置されたケーシングが受ける影響とその要因につい て検討しまたメタンハイドレート層掘削に関連した ゲーシングの使用実績と事故事例の調查，断熱ケーシン グソチュービングの構造, 性能, 使用実績などを調查し た。これらの調査検討の結果, メタンハイドレートの分 解・生成によるケーシング事故の実例はなく，また八1
ドレート再生成時の膨張圧もケーシングに与える影響は 大きくないものと判断した。これらの結果から，掘削 中, 掘削停止期間中を通じて,メタンハイドレート層が ケーシングに与える強度的影響はほとんざなく，ハイド レート平衡圧力に耐える管種を選びさえすれば通常の ケーシング設計法を適用するだけでよいことが明らかと なった。

\subsection{5 泥水システムの開発}

(1) 目 的

メタンハイドレート層を掘削する上で，地層中のメ夕 ンハイドレートを分解させず，かつ坑井内に八イドレー 卜を生成させないという相反する要求を満たす掘削泥水 システムを構築する。また泥水中でのメタンハイドレー 卜の生成分解曲線, 泥水の熱物性, そして低温下におけ る流動特性などを明らかにする。

(2) 概 要

メタンハイドレート層の掘削においては，地層中に存 在する天然ハイドレートの分解を極力抑制することに よって，研究対象であるハイドレートをそのままの状態 で地上に回収するととあに，分解ガスによるガスキック ないしブローアウトの危険を生じさせない，という配慮 が必要である。一方，ハイドレート賦存環境の特徴であ る大水深の高王・低温環境においては, 噴出防止装置や チョークラインの中などで泥水中にハイドレートが生成 して，それらを閉塞してしまう危険性があることにあ配 慮しなければならない。これらの相反する要求を同時に 満たすためには，ハイドレートの熱力学的平衡条件のみ ならず，速度論的生成分解抑制条件をも考慮した新しい タイプの泥水システムを構築する必要がある。また，従 来の油・ガス井掘削に用いられた泥水では，主として高 温度下での特性が問題になったが，ハイドレート坑井の 掘削泥水では，低温下における流動特性などの性質を明 らかにする必要がある。大水深掘削用泥水の実績調查を もとに，ハイドレートの生成抑制泥水の基本となる泥水 として2種類のポリマー泥水を選択し，低温下における 流動特性や脱水特性などの評価試験を実施し, 掘削泥水 として問題がないことを確認した。ハイドレート安定促 進剤 (分解抑制剂) の候補物質の調查檢討を行った結 果, 天然高分子ポリマーが速度諭的安定促進剤として実 用の可能性があることを確認した。

\subsection{6 泥水冷却技術の開発}

(1) 目 的

日本周辺海域でのハイドレート坑并掘削に使用できる 実用的な泥水冷却システムを設計・製作する。海洋掘削 リグに搭載するという条件から，冷却能力だけでなく， 搭載重量, 消費電力, 設置スペースほかの制約について 
も配虑する。

(2) 概 要

地層中のメタンハイドレートをできるだけ分解させな いように坑井を掘削するためには，掘削泥水を彾却して 八イドレート層の温度上昇を防ざ，相平衡状態をハイド レートの分解抑制側に維持することが最も有効な方法の 1つとされている。日本近海でのハイドレート坑井の掘 削には非現実的とも言えるほど巨大な泥水冷却装置が必 要になるという計算結果が得られ，冷却方法の最適化亡 装置の規模縮小の必要性が指摘され，泥水冷却装置の小 型化の検討を実施した。この結果，「表層海水利用十予 冷却方式」の装置について設計を実施している。

\subsection{7 コアサンプル採取技術の開発}

(1) 目的

原位置状態でのメタン八イドレートサンプルを確実に 採取するためのコアサンプラーとして, 压力と温度を原 位置状態に維持したままのコア採取が可能な, ワイヤラ イン回収方式のコアサンプラーを設計・製作する。

(2) 概 要

メタンハイドレートの成因，物性，地層中での分布な どの研究を進めるとともに，その資源としてのポテン シャルを調査するためには，原位置状態の圧力之温度を 維持したメタン八イドレートのコアサンプルを採取する ことが不可火である。

既存の圧力・温度保持コアサンプラーの市場調査を実 施し, 圧力保持に関してはODP (ocean drilling program)のワイヤライン回収方式のものと, BHI 社のド リルパイプ揚降管方式の 2 種類があり, 温度保持機能を 持つコアサンプラーはないことが判明したため, 圧力・ 温度保持コアサンプラー（PTCS）の設計・製作を実施 した。PTCSワイヤライン回収方式,コア径 2-5/8”，コ 了採取長 $3 \mathrm{~m}$, 圧力保持能力 $3,500 \mathrm{psi}$, ビット径 10-5/ 8”，扣よび使用ドリルパイプ径 6-5/8”などの仕様であ る。またコアサンプラーの組立・分解用ッールなどの付 随ツールス類とサービスユニットの設計・製作，ならび にインナーバレルの昇降を可能にする大内径のドリルパ
イプとドリルカラーの選定・調達が必要である。一方, カナダの実証井にて実際にコアリングを行い，コアサン プラーおよび付随ッール/設備の各種機能を検証・評価 したところ, 種々の問題点が発見され設計変更が行われ ている。

\section{3. 将来への展望}

掘削技術研究室における研究開発の目的は, 石油・ガ スの探鉱開発において新たな価值を生み出すことであ る。そして研究開発の内容は，上述したような新技術の 開発・検泟のほかに, 既存技術の改良・応用, 基礎研究 の実施であり, 成果物として掘削機器, プログラム、マ ニュアルおよび新しい知見などが開発・構築され，また 国内石油開発関連会社に技術移転されている（表 3, 表 4 )。これら個々の成果が本邦石油開発業界に普及し, 少なからず当研究室がその役割を果たしていると確信す るあのの, 本当にそれが十分に業界に反映されているか 疑問視されていることあ否めない。このような状況を改 善するために，今後は個々の成果物の普及だけでなく， これらの技術を含む掘削作業全般および生産性向上につ いて,コスト計算を伴う総合的な評価を実施するほうが 業界に対する貢献度が高いと考える。しかしその実施に 際しては, 国内石油開発会社のフィールド条件および開 発方針などにおいて数々の制約があり, 国内では困難で あると予想される。したがって研究開発成果の総合評価 に関しては, 産油国との共同研究として海外のフィール ドにおいて推進することが望ましいと考えている。この ような産油国との共同研究が，本邦石油開発会社による 新規油田の開発ならびに枯渴油田の再開発のような事業 に結びつく端緒となることを期待したい。

以上の構想を踏まえて，掘削技術研究室では，平成 12 年度からの研究開発テーマとして以下のような新規テー マを提案する。

\section{1 新規研究開発テーマについて}

近年の石油の探鈸開発作業に扔ける特殊水平坑井の採 用や大水深掘削などの必要性の增加により，掘削技術は

表 3 掘削技術研究室が開発した主なソフトウェア

\begin{tabular}{|c|c|}
\hline プログラム名 & 内 \\
\hline ・ビットハイドロリクス最適化プログラム & $\begin{array}{l}\text { 泥水循環系の圧力損失を計算し, インパクトフォースや } \\
\text { 水馬力が最大になるポンプレートなどを求める }\end{array}$ \\
\hline ・キックコントロールシミュレーションプログラム & 二相流モデルによるキックコントロールシミュレーション \\
\hline ・簡略解法による三次元 BHA 挙動解析プログラム & 支配方程式を簡略化して線型方程式で BHA 挙動を求める \\
\hline •有限要素法による三次元 BHA 挙動解析プログラム & 有限要素法により BHA 挙動を動的に解析する \\
\hline$\cdot \mathrm{J}-\mathrm{CASING}$ & 水平坑井/高傾斜井用ケーシングプログラム \\
\hline$\cdot \mathrm{J}-\mathrm{DRILL}$ & 坑跡最適化およびドリルストリングデザインプログラム \\
\hline
\end{tabular}


表 4 掘削技術研究室関連の特許

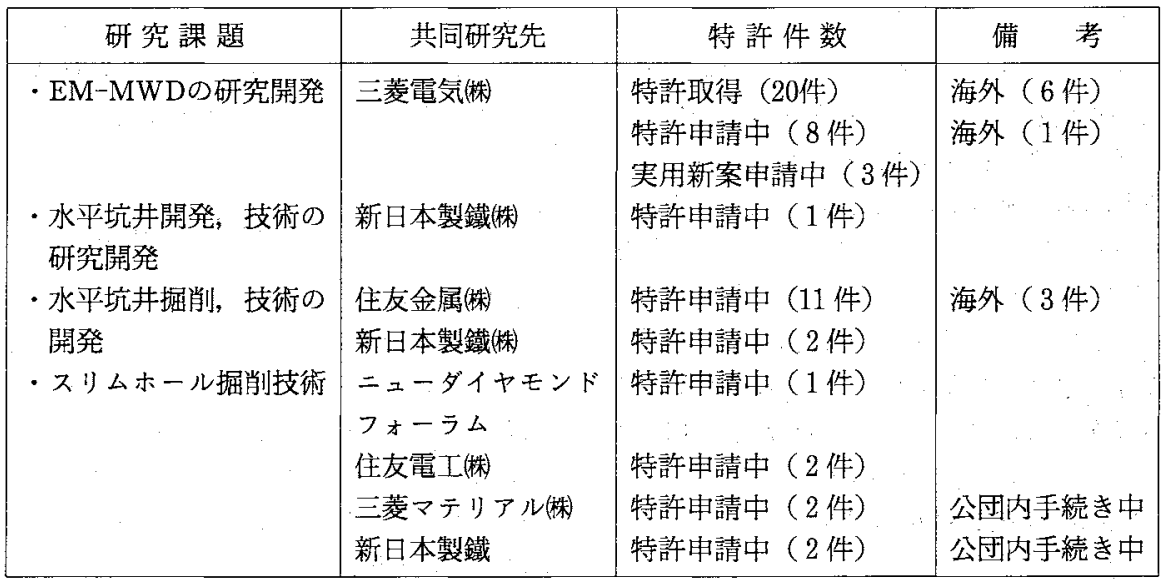

従来より高度かつ複雑なむのとなっており，新技術のみ ならず既存技術においても石油会社やサービスカンパ ニー/コントラクターによる技術革新が求められている。 また本邦石油会社は経験の少ない地域で発生する掘削上 の作業障害へのスピーディーかつ効果的な対応も求めら れている。そこで掘削作業の計画段階で作業障害を未然 に防止し，実作業において作業障害に遭遇した場合に あ，過去の経験や知見をむとに迅速に対策を講ずること が可能となり，掘削作業の効率化やコスト削減あるいは 最新技術の有効活用に結びっくように本邦石油会社の操 業を支援する。

\subsection{1 掘削作業障害対策技術の研究開発}

石油会社においては, 坑井の大深度化, 大水深化，特 殊坑井化，あるいは経験の少ない地域での掘削作業の増 加などにより，掘削作業中に遭遇する作業障害の増加が 䯚念されている。そのような状況下で地域的な特性によ り，幾つかの事例として，次のような新たな掘削作業障 害が摘出され最新技術の採用が求められている。

・ 火山岩掘削時の低掘進率（日本やべトナム）

- 応力場に起因する琉壁の不安定性（南米や中央アジ r)

・セメンチングの不良によるケーシングの腐食（中東）

・環境保護の高まりによる HSE (health, safety and environment) 基準の再構築（北海や中東）

・生産性向上のための坑井の特殊化（中東）

よって，本研究開発テーマでは，これらの作業障害対 策技術や作業障害を引き起こすことなく最新技術が採用 できるように，それぞれの課題について調查および研究 開発を進める。

\section{3 .2 掘削作業支援システムの研究開発}

上述した研究開発より得られる知見は，石油会社各社
が基礎となる技術情報を共有し，それらを効率的に利用 できてはじめて有効なものとなり，掘削作業の計画段階 あるいは帮作業における掘削作業障害の対策技術として 利用可能となる。そこで，石油会社が基礎となる技術情 報を共有し，国内外での掘削作業を効率的に実施するこ とができるよう，掘削作業にかかわる新技術，最新情報 や本邦の掘削技術者により有効活用が望まれる掘削ソフ トゥェア，デー夕集，マニュアル集，サービスカンパ ニー/コントラクター情報などを総合的に蓄積し，開示 できるシステムを構築する。さらに，掘削作業障害に遭 遇した場合や新たな技術を導入する際，TRC と本邦石 油会社との技術的な検討が可能となるようなコミュ二 ケーションシステムを併せ持つあのとする。同システム を構成する情報は以下のとおりである。

掘削最新技術（大水深 [海底仕上げ， コイルド チュービング，アンダーバランス，マルチラテラル [任 上げ］水平掘，エクステンドリーチウェル，低比重セメ ントスラリー，HSE 対策にか，掘削作業障害対策技術 （抑留，暴噴，逸泥；セメンチング不良，坑壁の不安定 性，低掘進率ほか)，掘削作業障害事例集，作井デー夕 集，掘削作業マニュアル集，国内の石油関連会社活動状 況，TRC の研究内容，コントラクター・サービスカン パニーのサービス情報, 各種エンジニアリング用ソフト ウェア。

なおっこれらの研究開発は特別研究として予定している。

\section{SI 単位換算係数}

$$
\begin{array}{ll}
\text { inch } \times 2.54^{*} & \mathrm{E}-02=\mathrm{m} \\
\mathrm{psi} \times 6.894757 & \mathrm{E}+03=\mathrm{Pa} \\
\operatorname{kgf} \times 9.80665 * & =\mathrm{N}
\end{array}
$$

